\title{
University Faculty's Perspectives on the Roles of E-Instructors and Their Online Instruction Practice
}

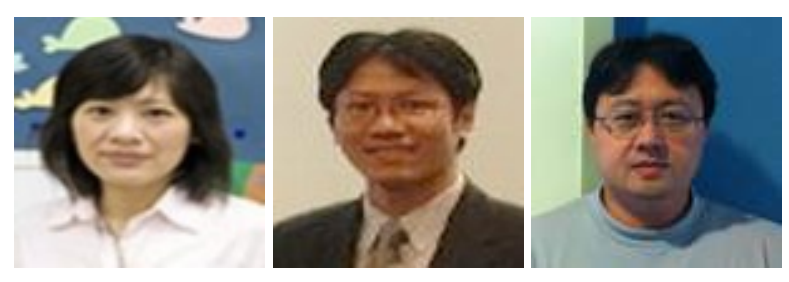

Chiungsui Chang ${ }^{1}$, Hun-Yi Shen ${ }^{1}$, and Eric Zhi-Feng Liu²

${ }^{1}$ Tamkang University, Taiwan, ${ }^{2}$ National Central University, Taiwan

\section{Abstract}

Despite the rapid use of e-Learning in higher education, the beliefs of instructors about and their practices during online instruction have been seldom addressed. This study explores the role perceptions of e-instructors in higher education. In total, 106 instructors from 20 Taiwanese universities filled out a questionnaire. Analytical results indicate that "content expertise" and "instructional designer" are perceived by university faculty as the key components in e-instruction in higher education. A gap exists between ideal and practical roles of e-instructors in higher education. Role perceptions and rolebased practices of e-instructors in higher education differ significantly in terms of gender and teaching experience. This study also provides suggestions for e-instructor training.

Keywords: Roles of e-instructor; online instruction; faculty's perceptions and practices; higher education 


\section{Introduction}

Over the last decade, the number of colleges and universities offering e-Learning courses has increased dramatically, meaning that the number of faculty teaching online courses has also increased (Allen \& Seaman, 2008; Aspden \& Helm, 2004; Barker, 2003; Wallhaus, 2000; West, Waddoups, \& Graham, 2007). As the number of online university courses is increasing rapidly, the awareness of the roles of e-instructors has also increased. Changes in the roles of e-instructors are particularly important when students engage in e-Learning (Barker, 2002; Denis, Watland, Pirotte, \&Verday, 2004). Therefore, e-instructors now play a very important role in e-Learning success and face many new challenges in higher education (Davidson-Shivers, Salzaar, \& Hamilton, 2005; Goold, Coldwell, \& Craig, 2010; Hass \& Senjo, 2004; J ohnson, 2008; Keengwe \& Kidd, 2010; McQuiggan, 2007; Morris, Xu, \&Finnegan, 2005; Tao \&Yeh, 2008).

Ryan, Scott, and Walsh (2010) proposed that e-instructors must be aware of issues associated with complex information. One primary challenge for e-instructors is to provide clear guidance during distance learning. In the conventional classroom, verbal and nonverbal communication delivers information and knowledge and helps students understand learning tasks. Changing communication modes requires e-instructors to adapt to e-Learning environments (Ryan, Scott, \& Walsh, 2010). A large body of literature suggests that the roles of e-instructors may be more complex than those of traditional instructors (Baran, Correia, \& Thompson, 2011; Barker, 2002; Bawane \& Spector, 2009; Berge, 2001; Craig, Goold, Coldwell, \& Mustard, 2008; Denis, Watland, Priotte, \& Verday, 2004; Goodyear et al., 2001). Teacher beliefs typically encompass values, attitudes toward learning and learners, and conceptions of teacher roles and teaching practices. Therefore, information and knowledge about teacher beliefs are very important to improving instructional effectiveness (Farrell \& Kun, 2008). However, most discussions of the relationship between teacher beliefs and teacher practices have focused on secondary and primary school teachers. Little attention has been paid to this relationship in the university or college context (Kane, Sandretto, \& Heath, 2002). The online environment changes the fundamental nature of the interaction between the teacher, student, and content. Teachers are expected to adopt more facilitative approaches in online instruction; there is a strong need to require a re-examination of the roles teachers take and practice (Baran, Correia, \& Thompson, 2011). Understanding what is lacking in online instruction is critical to help researchers and practitioners develop online programs and supports for e-instructors in higher education. Thus, this study attempts to answer the following questions : (1) Does a relationship exist between e-instructor beliefs about instructional roles and practices? (2) Do beliefs about the roles of e-instructors differ significantly? (3) Do online instructional practices of einstructors differ significantly?

\section{The New Faculty Roles in Online Instruction}

As online instruction is becoming increasingly common, the importance of exploring challenges faced by e-instructors has increased dramatically. O’Neil (2006) argued that 
the role of an online instructor requires a paradigm shift in perceptions of instructional time and space, virtual management techniques, and ways of engaging students during e-Learning. Berge (2001) characterized the roles of e-instructors as (1) teaching, (2) socializing, (3) management, and (4) technology integrating. E-instructors are also expected to have the necessary technical, counseling, and facilitation skills to integrate technology and teaching to improve personal, active, and cooperative learning strategies. Ryan et al. (2000) proposed that the main role of online instructors is facilitator. E-instructors must facilitate the transition for students from the classroom to an online learning environment as well as guide students through the complexities of learning activities (Salmon, 2003). Goodyear, Salmon, Spector, Steeples, and Tickner (2001) demonstrated that the key roles of e-instructors are (a) process facilitator, (b) consultant/ counselor, (c) assessor, (d) researcher, (e) content expert, (f) technician, (g) designer, and (h) manager/administrator. A process facilitator promotes a range of online activities that support student learning, particularly those associated with highlevel thinking. A consultant/counselor advises or counsels students; an assessor grades student work and provides feedback; a researcher adds new knowledge to content areas; a technician makes technology decisions or choices to improve the e-Learning environment for learners; a designer designs learning tasks; and a manager must manage students to maintain successful online learning experiences. For example, einstructors may promote online debates, identify controversial issues, and encourage discussion to generate additional evidence, and to summarize the discussion (Goodyear et al., 2001). Spector and de la Teja (2001) suggested that e-instructors must have the ability to manage learner time for reflection, keep discussions active, and organize discussions for use in curricula. Denis, Watland, Pirotte, and Verday (2004) defined the e-instructor profession via seven roles-content facilitator, metacognition facilitator, process facilitator, advisor/counselor, assessor, technologist, and resource provider. They considered these roles essential for delivering online courses. Bawane and Spector's (2009) study proposed the roles of e-instructor include professional, pedagogical, social, evaluator, administrator, technologist, advisor/counselor, and researcher. Similarly, Guasch, Alvarez, and Espasa (2010) reported that instructors play the multiple roles of design/planning, social, instructive, technological, and management in online environments. Notably, these roles and those proposed by Goodyear et al. (2001) are similar.

Moreover, Taiwan's e-Learning Service Certification program (Chen, 2009) identified 27 benchmarks considered essential to ensure excellence in online instruction. These benchmarks were distilled from the most popular strategies employed by colleges and universities, and they were divided into eight criteria, including (1) learner support, (2) faculty support, (3) curriculum development, (4) instructional design, (5) instructional process, (6) organizational support, (7) technology, and (8) assessment and evaluation. With respect to the quality of e-learning courses, the seven dimensions of e-instructors' beliefs about roles and practices are related to the eight criteria in Taiwan's e-Learning Service Certification program. Therefore, the professional development for e-instructors was designed in accordance to the criteria for the design of training actions in virtual 
learning environments. In terms of professional development, issues of pedagogical intent and the selection of appropriate teaching and learning technologies appear to be greater concerns in the arena of quality online learning.

\section{Personal Background Characteristics}

Many studies have identified differences in attitudes toward technology use based on gender, age, and education level (Ahadiat, 2005; Sieverding \& Koch, 2009). Females, the elderly, and those with low education levels had poorer attitudes toward technology than males, the young, and the highly educated, respectively (Ahadiat, 2005). Several studies demonstrated that male teachers are typically more interested in technology use in the classroom than female teachers (Ahadiat, 2005; Vekiri, 2010). Additionally, female faculty typically use computers less and have more negative attitudes toward computer use than males (Crooks, Yang, \& Duemer, 2003; Mitra, Lenzmeier, Steffensmeier, Avon, Qu, \& Hazen, 2000; Zhou \& Xu, 2007). Conversely, studies by Schifter (2002) and Fatt (2003) demonstrated that female teachers have significantly better attitudes toward technology than males. Furthermore, Meyer and Xu (2009) indicated that the teaching load remains consistent and a relatively strong relationship exists between teaching load and technology use by faculty.

According to Schifter (2002), faculty rank (i.e., lecturer, assistant professor, associate professor, and full professor) significantly impacts technology use. Status is important in academia as rights, privileges, and pay are commensurate with status. Lecturers are typically concerned about the compatibility of technology and instructional material. Further, administration exerted greater pressure on lecturers than status. These analytical results suggest that before hiring temporary teachers, lecturers, university managers, or program directors, a candidate's technical and computer skills should be assessed in relation to the overall goals and expectations of a university. Zayim, Yildirim, and Saka (2006) also noted that faculty rank and computer use self-efficacy are the two most powerful predictors of technology adoption. They demonstrated that faculty members with a rank lower than professor and faculty whose self-efficacy is strong are most likely to be early technology adopters. Moreover, appropriate levels of technical and administrative support must be provided to all teachers (Schifter, 2002).

\section{Research Methodology}

\section{Participants}

Based on data from Taiwan's Ministry of Education (MOE) (2008a), 68 universities offered 857 blended e-Learning courses via an e-Learning platform (e.g., WebCT or Moodle). This study randomly sampled roughly one-third of Taiwan's e-instructor population. That is, this study surveyed 277 instructors from 20 universities in Taiwan 
with experience teaching online courses. All subjects were asked to answer a questionnaire. The questionnaire and cover letter were distributed to subjects by researchers via mail. Confidentiality was guaranteed. In total, 106 instructors completed the questionnaire. Seven questionnaires lacking some responses were eliminated, leaving 99 valid questionnaires, for a valid response rate of $39.6 \%$. Briefly, the ratio of male faculty to female faculty was about $67 \%$ and the ratio of assistant professors to full professors was about $64 \%$ in Taiwan (MOE, 2008b). Similarly, most instructors in this study were male (63\%). Roughly, $22 \%$ of respondents were full professors, $35 \%$ were associate professors, and 20\% were assistant professors. Most instructors (82\%) received little or some training support, while $25 \%$ of instructors received sufficient training and support for online instruction.

\section{Instrument}

Data were collected via the questionnaire. The questionnaire, consisting of three parts, included (a) demographic information, (b) perceptions of e-instructor's roles, and (c) practices of e-instructor's roles. The Perceptions and Practices of E-Instructors toward Online Instruction Questionnaire (PPEOIQ) (see Appendix) in this study was defined using seven dimensions, namely, (a) instructional design (e.g., "I can design assignments to enhance students' interactions"), (b) facilitating learning (e.g., "I can facilitate participants' discussion and help them focus on the related learning goals"), (c) learning assessment (e.g., "In order to match the course instructional goals, I can plan appropriate evaluation formats"), (d) technology use (e.g., "According to instructional goals, I can choose technology appropriately for my online course"), (e) administrative management (e.g., "I can meet with e-tutors regularly in order to ensure the online instruction well-quality", (f) content expertise (e.g., "I can prepare my instructional material in advance in order to deliver content to participants"), and (g) research development (e.g., "Based on instructional pedagogical theories, I can develop research issues related to the online instruction"). Responses to each item associated with each dimension were on a four-point Likert scale, ranging from 1 for "strongly disagree" to 4 for "strongly agree." Demographic information collected were gender, teaching field, and years of teaching experience. For perceptions of online instruction (45 items), participants were asked to indicate their belief on the importance rank order of online instruction roles of e-instructors. For online instruction practices (45 items), participants identified their practices, priorities, and online instruction roles of einstructors.

Survey questions were created utilizing literature review research. A panel of experts (six e-learning experts with more than five years of experience) was asked to review the instrument for content and face validity. To enhance the validity of the instrument, the instrument was pilot tested with a group of 25 teachers with online teaching experience from one university. The value of the Cronbach's a for each dimension was high (0.720.89). The overall alpha reliability coefficients for the perceptions and practices of einstructors toward the online instruction questionnaire (PPEOIQ) were 0.96 \& 0.97. 
The alpha reliability coefficients suggest that the questionnaire has acceptable internal consistency.

\section{Design and Data Analysis}

Data of the perceptions and the practices of e-instructor's roles were analyzed using descriptive statistics and sorted by the means. Pearson's correlation was performed between the perceptions and the practices of e-instructor's roles. T-test was conducted for gender on each dimension of the perceptions and the practices. One-way ANOVA was run for faculty rank, online instruction experience, training support, and teaching load on each dimension of the perceptions and the practices. LSD was performed as the post hoc analysis. Statistical tests were performed using an alpha of .05.

\section{Results}

Descriptive statistics show that the ranked importance for the seven e-instructor dimensions was (1) content expertise, (2) instructional design, (3) learning assessment, (4) administrative management, (5) facilitating learning, (6) technology use, and (7) research development (Table 1). In other words, participants believed that content expertise $(\mathrm{M}=3.52)$, instructional design $(\mathrm{M}=3.45)$, and learning assessment $(\mathrm{M}=$ 3.24) were the most important roles for e-instructors of online courses. Technology use $(\mathrm{M}=3.15)$ and research development $(\mathrm{M}=3.16)$ were the least important roles for $\mathrm{e}-$ instructors. Furthermore, analytical results show that the ranked order by the basis of the mean for practices for these seven e-instructor dimensions was (1) content expertise, (2) administration management, (3) instructional design, (4) technology use, (5) learning assessment, (6) research development, and (7) facilitating learning. Pearson's correlation coefficient provides strong evidence that the importance of an e-instructor's role and the actual e-instructor's role in online instruction practices were moderately correlated $(r=.47-.70)$. 
Table 1

Pearson's r between Perception and Practice of E-Instructors toward Online Instruction

\begin{tabular}{|c|c|c|c|c|c|c|c|}
\hline \multirow[b]{2}{*}{ Dimension } & \multicolumn{3}{|c|}{ Perception } & \multicolumn{3}{|c|}{ Practice } & \multirow[b]{2}{*}{ Pearson's r } \\
\hline & Mean & SD & Rank & Mean & SD & Rank & \\
\hline Instructional design & 3.45 & .34 & 2 & 3.00 & .49 & 3 & $.58 * *$ \\
\hline Facilitating learning & 3.19 & .49 & 5 & 2.64 & .63 & 7 & $.67^{* *}$ \\
\hline Learning assessment & 3.24 & .41 & 3 & 2.85 & .59 & 5 & $.60 * *$ \\
\hline Technology use & 3.15 & .48 & 6 & 2.91 & .61 & 4 & $.47^{* *}$ \\
\hline $\begin{array}{l}\text { Administration } \\
\text { management }\end{array}$ & 3.20 & .49 & 4 & 3.05 & .63 & 2 & $.61^{* *}$ \\
\hline Content expertise & 3.52 & .44 & 1 & 3.22 & .56 & 1 & $.66^{* *}$ \\
\hline Research development & 3.16 & .50 & 7 & 2.80 & .66 & 6 & $.70 * *$ \\
\hline Total & 3.28 & .37 & & 2.92 & .49 & & $.67^{* *}$ \\
\hline
\end{tabular}

$* * \mathrm{p}<0.01$

\section{Gender}

Statistically significant differences existed between male and female e-instructors in their perceptions toward the roles of e-instructors (Table 2). Results of t-tests in all the seven dimensions (instructional design, facilitating learning, learning assessment, technology use, administration management, content expertise, and research development), the mean scores for perceptions of female e-instructors (3.61, 3.42, 3.41, $3.34,3.44,3.64$, and 3.36 respectively) were significantly greater than those of males (3.34, 3.06, 3.15, 3.04, 3.08, 3.43, and 3.08 respectively).

Statistically significant differences existed between male and female e-instructors in their practice of e-Learning instruction (Table 2). Except for technology use, results of ttests show the mean scores for practices of female e-instructors (3.25, 2.91, 3.06, 3.31, 3.39 , and 3.01 respectively) were significantly greater than those of males $(2.88,2.48$, $2.72,2.92,3.13$, and 2.70 respectively) in instructional design, facilitating learning, learning assessment, administration management, content expertise, and research development. 
Table 2

Perception and Practice between Male and Female E-Instructors toward Online Instruction

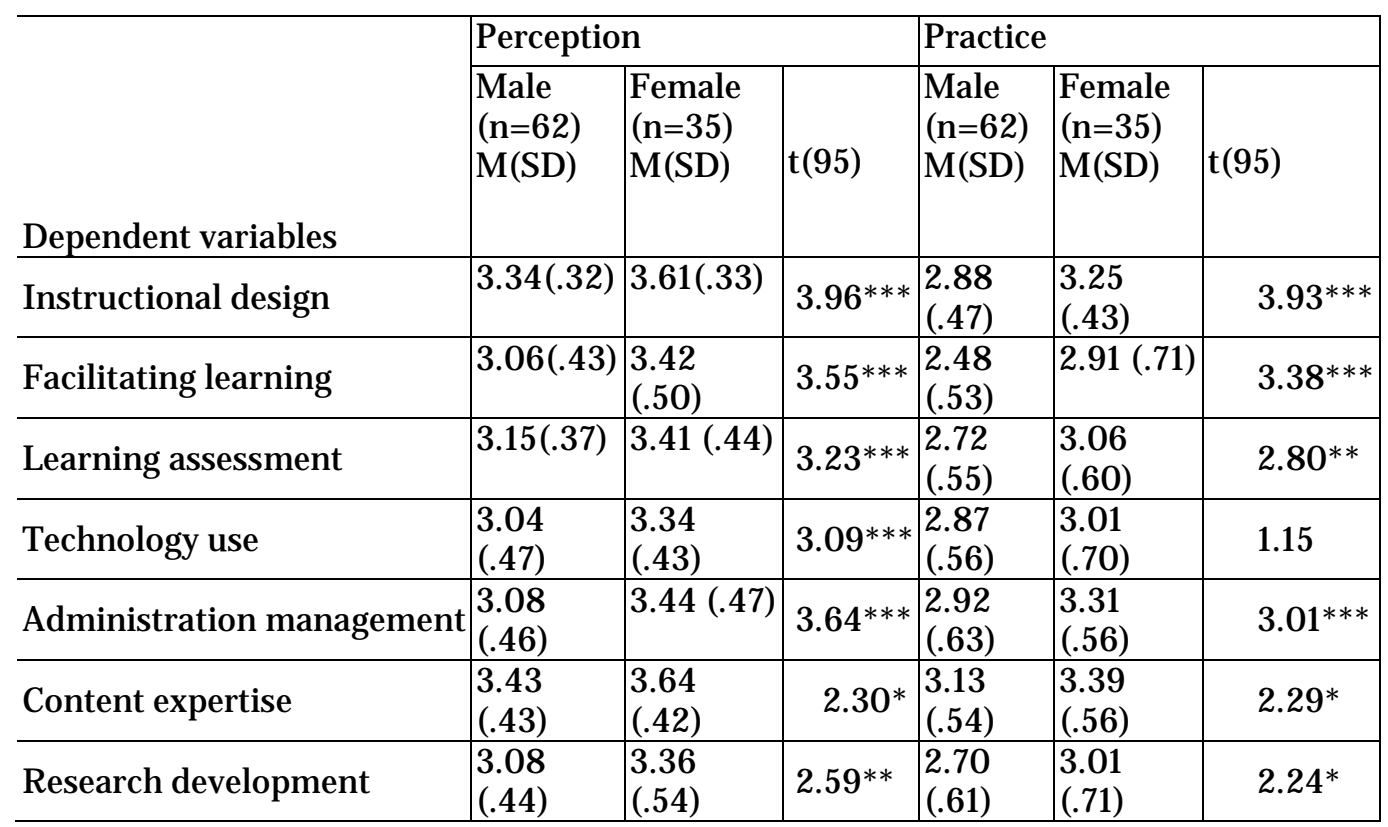

$* \mathrm{p}<.05 . * * \mathrm{p}<.01 . * * * \mathrm{p}<.001$

\section{Faculty Rank}

Notably, no statistically significant difference existed between e-instructors' ranks of perceptions toward e-instructor roles and practices using one-way ANOVA. The results show that e-instructors with different ranks have the same perceptions and practices about the roles of e-instructor. In perception, full professor reported the highest mean scores on content expertise $(M=3.48)$, instructional design $(M=3.46)$, learning assessment $(\mathrm{M}=3.30)$, administration management $(\mathrm{M}=3.27)$, technology use $(\mathrm{M}=$ 3.14), facilitating learning $(M=3.22)$, and research development $(M=3.21)$, while assistant professor reported the highest mean scores on content expertise ( $M=3.65)$, instructional design $(\mathrm{M}=3.35)$, learning assessment $(\mathrm{M}=3.15)$, technology use $(\mathrm{M}=$ 3.13), administration management $(\mathrm{M}=3.12)$, facilitating learning $(\mathrm{M}=3.08)$, and research development $(\mathrm{M}=2.96)$.

In practice, full professor reported the highest mean scores on content expertise ( $\mathrm{M}=$ 3.27), administration management $(M=3.16)$, instructional design $(M=3.08)$, technology use $(M=3.03)$, research development $(M=2.93)$, learning assessment $(M=$ 2.88), and facilitating learning $(\mathrm{M}=2.70)$, while assistant professor reported the highest mean scores on content expertise $(M=3.28)$, instructional design $(M=2.94)$, 
administration management $(\mathrm{M}=2.88)$, technology use $(\mathrm{M}=2.86)$, learning assessment $(M=2.70)$, research development $(M=2.56)$, and facilitating learning $(M$ $=2.49$ ).

\section{Online Instruction Experience}

Regarding the perceptions of online instruction, a significant difference existed among e-instructors with different experiences in 'Facilitating learning' dimension (Table 3). Additionally, regarding the practices of online instruction, a significant difference existed among e-instructors with different experiences in 'Facilitating learning dimension (Table 4) in one-way ANOVA and LSD as post hoc analysis method.

Table 3

Perceptions of Different Experiences of Online Instruction

\begin{tabular}{|c|c|c|c|c|c|c|c|}
\hline $\begin{array}{l}\text { Dependent } \\
\text { variables }\end{array}$ & $\begin{array}{l}\text { Less than } \\
1 \mathrm{yr}(\mathrm{n}=18) \\
\mathrm{M}(\mathrm{SD})\end{array}$ & $\begin{array}{l}1 \text { to } 2 \text { yrs } \\
(\mathrm{n}=15) \\
\mathrm{M}(\mathrm{SD})\end{array}$ & $\begin{array}{l}2 \text { to } 3 \\
\text { yrs } \\
(n=17) \\
M(S D)\end{array}$ & $\begin{array}{l}3 \text { to } 4 \text { yrs } \\
(\mathrm{n}=20) \\
\mathrm{M}(\mathrm{SD})\end{array}$ & $\begin{array}{l}>4 \text { years } \\
(\mathrm{n}=27) \\
\mathrm{M}(\mathrm{SD})\end{array}$ & $F(5,91)$ & LSD \\
\hline $\begin{array}{l}\text { Instructional } \\
\text { design }\end{array}$ & 3.48 (.39) & $3.51(.35)$ & $\begin{array}{l}3.38 \\
(.39)\end{array}$ & $3.52(.30)$ & $3.35(.30)$ & 0.96 & \\
\hline $\begin{array}{l}\text { Facilitating } \\
\text { learning }\end{array}$ & $3.32(.51)$ & $3.42(.42)$ & $\begin{array}{l}3.22 \\
(.55)\end{array}$ & $3.25(.44)$ & $2.94(.42)$ & $2.56^{*}$ & $\begin{array}{l}1>5 ; 2>5 ; \\
4>5\end{array}$ \\
\hline $\begin{array}{l}\text { Learning } \\
\text { assessment }\end{array}$ & $3.32(.53)$ & $3.33(.42)$ & $\begin{array}{l}3.22 \\
(.42)\end{array}$ & $3.28(.33)$ & 3.16 & 0.55 & \\
\hline $\begin{array}{l}\text { Technology } \\
\text { use }\end{array}$ & 3.26 (.66) & $3.16(.50)$ & $\begin{array}{l}3.17 \\
(.42)\end{array}$ & 3.18 (.39) & $3.08(.49)$ & 0.30 & \\
\hline $\begin{array}{l}\text { Administration } \\
\text { management }\end{array}$ & 3.43 & $3.19(.52)$ & $\begin{array}{l}3.16 \\
(.51)\end{array}$ & $3.28(.48)$ & 3.10 (.47) & 0.97 & \\
\hline $\begin{array}{l}\text { Content } \\
\text { expertise }\end{array}$ & $3.66(.41)$ & $3.60(.36)$ & $\begin{array}{l}3.46 \\
(.45)\end{array}$ & $3.53(.42)$ & 3.39 & 1.00 & \\
\hline $\begin{array}{l}\text { Research } \\
\text { development }\end{array}$ & $3.14(.59)$ & 3.22 (.39) & $\begin{array}{l}3.13 \\
(.52)\end{array}$ & $3.21(.51)$ & $3.20(.52)$ & 0.15 & \\
\hline
\end{tabular}

$* \mathrm{p}<.05$; $1=$ less than one year; $2=$ one to two years; $3=$ two to three years; $4=$ three to four years; $5=$ more than four years 
Table 4

Practice of Different Experiences of Online Instruction

\begin{tabular}{|c|c|c|c|c|c|c|c|}
\hline $\begin{array}{l}\text { Dependent } \\
\text { variables }\end{array}$ & $\begin{array}{l}\text { Less } \\
\text { than } 1 \\
\operatorname{yr}(\mathrm{n}=18) \\
\mathrm{M}(\mathrm{SD})\end{array}$ & $\begin{array}{l}1 \text { to } 2 \text { yrs } \\
(\mathrm{n}=15) \\
\mathrm{M}(\mathrm{SD})\end{array}$ & $\begin{array}{l}2 \text { to } 3 \text { yrs } \\
(n=17) \\
M(S D)\end{array}$ & $\begin{array}{l}3 \text { to } 4 \text { yrs } \\
(n=20) \\
M(S D)\end{array}$ & $\begin{array}{l}>4 \text { years } \\
(\mathrm{n}=27) \\
\mathrm{M}(\mathrm{SD})\end{array}$ & $F(5,91)$ & LSD \\
\hline $\begin{array}{l}\text { Instructional } \\
\text { design }\end{array}$ & $\begin{array}{l}3.18 \\
(.52)\end{array}$ & $3.14(.45)$ & $2.97(.49)$ & 3.10 & $2.86(.40)$ & 1.48 & \\
\hline $\begin{array}{l}\text { Facilitating } \\
\text { learning }\end{array}$ & $\begin{array}{l}2.85 \\
(.72)\end{array}$ & $2.88(.58)$ & $2.58(.75)$ & $2.76(.70)$ & $2.38(.40)$ & $2.29 *$ & $\begin{array}{l}1>5 ; \\
2>5 ; \\
4>5\end{array}$ \\
\hline $\begin{array}{l}\text { Learning } \\
\text { assessment }\end{array}$ & $\begin{array}{l}2.98 \\
(.59)\end{array}$ & $2.85(.65)$ & $2.74(.67)$ & $3.03(.63)$ & $2.78(.39)$ & 1.68 & \\
\hline Technology use & $\begin{array}{l}2.95 \\
(.65)\end{array}$ & $2.95(.57)$ & $2.97(.50)$ & $2.98(.68)$ & $2.95(.57)$ & 2.14 & \\
\hline $\begin{array}{l}\text { Administration } \\
\text { management }\end{array}$ & $\begin{array}{l}3.24 \\
(.67)\end{array}$ & $2.95(.66)$ & $3.01(.69)$ & $3.34(.61)$ & $2.95(.50)$ & 2.12 & \\
\hline $\begin{array}{l}\text { Content } \\
\text { expertise }\end{array}$ & $\begin{array}{l}3.41 \\
(.65)\end{array}$ & 3.28 & $3.21(.50)$ & 3.25 (.61) & $3.16(.52)$ & 1.16 & \\
\hline $\begin{array}{l}\text { Research } \\
\text { development }\end{array}$ & $\begin{array}{l}2.84 \\
(.68) \\
\end{array}$ & $2.85(.45)$ & $2.81(.68)$ & $2.86(.70)$ & $2.83(.69)$ & 0.75 & \\
\hline
\end{tabular}

${ }^{*} \mathrm{p}<05 ; 1=$ less than one year; $2=$ one to two years; $3=$ two to three years; $4=$ three to four years; $5=$ more than four years

\section{Training Support}

Regarding the perception of online instruction, no significant difference existed among e-instructors with different levels of training support in each dimension. However, regarding the practice of online instruction, significant differences existed for instructional design, learning assessment, and technology use among e-instructors with different levels of training support (Table 5) by the results of one-way ANOVA and LSD. The analytical result indicates that e-instructors who received enough training support performed better in the dimensions of instructional design, learning assessment, and technology use than e-instructors who receive some or little training support. 
Table 5

Practices toward Online Instruction among Different Training Support

\begin{tabular}{llllll}
\hline Dependent variables & $\begin{array}{l}\text { Little } \\
(\mathrm{n}=19) \\
\mathrm{M}(\mathrm{SD})\end{array}$ & $\begin{array}{l}\text { Some } \\
(\mathrm{n}=53) \\
\mathrm{M}(\mathrm{SD})\end{array}$ & $\begin{array}{l}\text { Enough } \\
(\mathrm{n}=25) \\
\mathrm{M}(\mathrm{SD})\end{array}$ & $\mathrm{F}(2,94)$ & LSD \\
\hline Instructional design & $2.88(.37)$ & $2.95(.55)$ & $3.24(.34)$ & $4.00^{*}$ & $3>1 ; 3>2$ \\
\hline Facilitating learning & $2.50(.31)$ & $2.61(.72)$ & $2.78(.60)$ & 1.20 & \\
\hline Learning assessment & $2.63(.37)$ & $2.81(.65)$ & $3.09(.52)$ & $3.70^{*}$ & $3>1 ; 3>2$ \\
\hline Technology use & $2.59(.47)$ & $2.88(.62)$ & $3.26(.53)$ & $7.64^{* *}$ & $3>1 ; 3>2$ \\
\hline Administration management & $2.92(.45)$ & $3.02(.67)$ & $3.25(.65)$ & 1.76 & \\
\hline Content expertise & $3.30(.51)$ & $3.13(.61)$ & $3.36(.47)$ & 1.68 & \\
\hline Research development & $2.72(.49)$ & $2.72(.72)$ & $3.07(.58)$ & 2.67 & \\
\hline
\end{tabular}

$* \mathrm{p}<.05 . * * \mathrm{p}<.01 ; 1=$ Little; $2=$ Some; $3=$ Enough

\section{Discussion}

This study investigated (a) the relationships between e-instructors' beliefs about roles and practices about online instruction, and (b) differences in perceptions and practices of online instruction among different e-instructors (e.g., gender, rank, experience, and training). The major findings are summarized as follows.

E-instructors considered 'content expertise' and 'instruction designer' as the two most important roles of e-instructors. Meanwhile, e-instructors ranked content expertise and administration management as the top two highest places as they performed e-Learning instruction. Surprisingly, e-instructors ranked 'administrative manager' as the fourth most important role; they ranked 'administrative manager' as the second highest place in their practice of online instruction. The administrative manager role comprises carrying out the pedagogical tasks related with course management, including establishing rules and regulations, student registration, and recordkeeping (Baran, Correia, \&Thompson, 2011; Guasch, Alvarez, \&Espasa, 2010). This may indicate that einstructors spent considerable time on administrative work while they taught online courses, due to the shortage of institution administrative supports (i.e., technical support for e-Learning platform or teaching assistant).

Moreover, e-instructors considered learning assessor' as the third most important role; they ranked learning assessor' as fifth place in their practice of online instruction. Furthermore, learning facilitator' was scored lowest for e-instructors perception, while they ranked it as the fifth most important role in their practice of online instruction. We are aware that today e-instructors face a growing demand from students to offer a more flexible, technology-enriched course delivery and they also face the pedagogical challenges to design innovative learning environments, which integrate technology 
enhancing students learning. In fact, it is the highest priority to redesign and rethink faculty multidimensional roles to be addressed in professional development programs to prepare to teach in online environments (Bawne \& Spector, 2009; Guasch, Alvarez, \& Espasa, 2010).

Experimental results also indicate that female e-instructors are statistically significantly higher than male e-instructors in their perceptions toward the roles of e-instructors and in their practices of e-learning instruction, except for technology use. This finding is in conflict with the finding obtained by Ahadiat (2005), but consistent with Schifter (2002) and Fatt (2003) indicating that female e-instructors may be more motivated and committed to online teaching. On the other hand, analytical results reveal that no significant differences existed between different e-instructor ranks, meaning that einstructor position does not affect their perceptions of, and practices during, online teaching.

Further, experimental results indicate that perceptions and practices associated with facilitating learning by e-instructors with a half year to four years of experience in teaching online were significantly different than those of e-instructors with more than four years of experience. One can infer that e-instructors with more than four years of experience had more online facilitating experiences with students and paid relatively more attention to other aspects of online instruction, such as instructional design, than facilitating learning.

No significant differences existed in e-instructor perceptions among those with different training support. However, significant differences existed in their practices. Einstructors with sufficient training support rated instructional design, learning assessment, technology use, and research development practices higher than did those with little or only some training support. This analytical result is in agreement with those of Arinto (2013), Munoz Carril, Gonzalez Sanmamed, and Hernandez Selles (2013), and Spector and de la Teja (2001) revealing that faculty-perceptions at the onset of a transition process from traditional classroom instruction to online teaching reflected a need for comprehensive faculty training.

In general, in addition to the content expertise, the top three prioritized roles for einstructors were administration management, instructional design, and technology use while e-instructors perform online instruction. Additionally, significant differences existed between genders and among different experience levels in online teaching and different amounts of training support. Although many studies have underscored the importance of a teacher's role in e-Learning, few empirical studies have investigated problems faced by teachers in their online roles. Based on the study of Nelson and Thompson (2005), faculty time, reward, workload, lack of administration support, cost, course quality, and equipment concerns are considered barriers to online teaching practices. Administrators must be aware of the fact that instructional and technical training and support are important influential factors in online teaching. 


\section{Conclusions}

The study findings enhance our understanding of the relationships between e-instructor perceptions of the importance of their roles and practices in online instruction. Overall, analytical results indicate that strong correlations exist between e-instructor perceptions and practices in each role (i.e., instructional designer, facilitator, assessor, technology integrator, administrative manager, content expert, and researcher). Among the seven dimensions, e-instructors perceived content expert and instructional designer as the most important roles during online instruction. Furthermore, mean scores for perceptions were higher than mean scores for practices for all roles. Experimental results indicate that a gap still exists between perceptions and practices as they relate to online instruction.

When this study was carried out, training was another issue for those who have and have not taught online. Without sufficient training, most faculty would not attempt to teach online (Daily, 2000; Fish \& Gill, 2009; Nelson \& Thompson, 2005). In this study, e-instructors with sufficient training scored practices higher than those with little or no training. Thus, it is important to note that routine training programs (i.e., basic computer skills) are not sufficient for the professional development of e-instruction practitioners. Munoz Carril, Gonzalez Sanmamed, and Hernandez Selles (2013) also pointed out facilitating students participation is what faculty identify as their greater training need in virtual learning environments. Based on the research participants' descriptions of their course design practices, it is clear that professional development in e-learning is a complex process that requires continuous engagement in instructional design work, critical reflection, and facilitation. Thus, training in course design should be integrated in faculty development programs in e-Learning to promote teacher empowerment and with appropriate and effective administrative and technology supports.

For individual differences in the seven dimensions of e-Learning instruction practices, female e-instructors expressed significantly more positive value beliefs and practices than males. This notable finding runs counter to the stereotypical impression of gendered difference in technology usage in higher education. Future research may identify the underlying factors that influence the perceptions of online instruction and online instruction practices of female e-instructors, such that appropriate strategies or interventions can be designed to enhance online instruction quality. Additionally, why the perceptions and practices of e-instructors with different online instruction experiences varied warrants examination. Future work also needs to be undertaken on improving the training support to prepare teachers to teach online.

The information obtained through this research study is highly relevant at both a local and a global level. We also hope that our study contributes to enrich the knowledge available on the roles of the e-instructors performing online teaching, whichthey may need to carry out their responsibilities and tasks. The limitations of this study are the fact that the sample size was somewhat small and their generalizability may be limited. 
Secondly, the data sources came from self-reported questionnaires. Alternative research methods like interviews could be combined with a survey in a future study.

\section{Acknowledgement}

This study was partially supported by the National Science Council, Taiwan, under grant numbers NSC 100-251-S-032-003-MY3. 


\section{References}

Ali, N., Hodson-Carlton, K., Ryan, M., Flowers, J ., Rose, M., \&Wayda, V. (2005). Online education: Needs assessment for faculty development. The J ournal of Continuing Education in Nursing, 36(1), 32-38.

Allen, I. E., \& Seaman, J . (2008). Staying the course: Online education in the United States. Needham MA: Sloan Center for Online Education.

Ahadiat, N. (2005). Factors that may influence or hinder use of instructional technology among accounting faculty. Campus-Wide Information Systems, 22(4), 210-232.

Albirini, A. (2006). Teacher's attitudes toward information and communication technologies: The case of Syrian EFL teachers. Computers \& Education, 47(4), 373-398.

Anderson, T., Rourke, L., Archer, W., \&Garrison, R. (2001). Assessing teaching presence in computer conferencing context. J ournal of Asynchronous Learning Networks, 5(2), 1- 17.

Arinto, P. B. (2013). A framework for developing competencies in open and distance eLearning. The International Review of Research in Open and Distance Learning, 14(1), 205-220.

Aspden, L., \&Helm, P. (2004). Making the connection in a blended learning environment. Educational Media International, 41(3), 245-252.

Barker, A. (2003). Faculty development for teaching online: Educational and technological issues. The J ournal of Continuing Education in Nursing, 34(6), 273-278.

Baran, E., Correi, A. P., \& Thompson, A. (2011). Transforming online teaching practice: crtical analysis of the literature on the roles and competences of online teachers. Distance Education, 32(3), 421-439.

Bawane, J ., \& Spector, J . (2009). Prioritization of online instructor roles: implication for competency-based teacher education programs. Distance Education, 30(3), 383-397.

Berge, Z. L. (2001). New roles for learners and teachers in online education. Retrieved from http:// www.globaled.com/ articles/ BergeZane2000.pdf

Chen, M. P. (2009). An evaluation of the elnp e-learning quality assurance program: Perspectives of gap analysis and innovation diffusion. Educational Technology \& Society, 12(1), 18-33.

Chen, T. L., \& Chen, T. J . (2006). Examination of attitudes towards teaching online courses based on theory of reasoned action of university faculty in Taiwan. British J ournal of Educational Technology, 37(5), 683-693. 
Conceicao, S. (2006). Faculty lived experiences in the online classroom. Adult Education Quarterly, 57(1), 26-45.

Conrad, D. (2004). University instructors' reflections on their first online teaching experiences. J ournal of Asynchronous Learning Networks, 8(2), 31-44.

Coppola, N. W., Hiltz, S. R., \& Rotter, N. G. (2002). Becoming a virtual professor: Pedagogical roles and asynchronous learning networks. J ournal of Management Information, 18(4), 169-189.

Crooks, S. M., Yang, Y., \& Duemer, L. S. (2003). Faculty perceptions of web-based resources in higher education. J ournal of Educational Technology Systems, 31(2), 103-113.

Daily, M. (2000). Faculty support for distance learning. Retrieved from http:// www.academyonline.con/ field/index.htm

Davidson-Shivers, G.V., Salazar, J ., \& Hamilton, K.M. (2005). Design of faculty development workshops: attempting to practice what we preach. College Student J ournal, 39(3), 528-540.

Eduwards, M., Perry, B., \&J anzen, K. (2011). The making of an exemplary online educator. Distance Education, 32(1), 101-118.

Farrell, T., \& Kun, S. (2008). Language policy, language teachers' beliefs, and classroom practices. Applied Linguistics, 29(3), 381-403.

Fatt, J . (2003). Perceptions of information technology in higher education. J ournal of Educational Technology Systems, 31(2), 115-142.

Fish, W. W., \&Gill, P. B. (2009). Perceptions of online instruction. The Turkey Online J ournal of Educational Technology, 6(1), 53-64.

Goodyear, P., Salmon, G., Spector, J . M., Steeples, C., \&Tickner, S. (2001). Competences for online teaching: A special report. Educational Technology Research and Development, 49(1), 65-72.

Goold, A., Coldwell, J ., \& Craig, A. (2010). An examination of the role of the e-tutor. Australasian J ournal of Educational Technology, 26(5), 704-716.

Guasch, T., Alvarez, I., \&Espasa, A. (2010). University teacher competencies in a virtual teaching/ learning environment: Analysis of a teacher training experience. Teaching and Teacher Education, 26, 199-206.

Haas, S. M., \& Senjo, S. R. (2004). Perceptions of effectiveness and the actual use of technology-based methods of instruction: A study of California criminal justice 
and crime-related faculty. J ournal of Criminal J ustice Education, 15(2), 263285.

Hara, N., \& Kling, R. (2000). Students' distress with a web-based distance education course: an ethnographic study of participants' experiences. Information, Communication \& Society, 3(4), 557- 579.

Heuer, B. P., \& King, K. (2004). Leading the band: the role of the instructor in online learning for educators. J ournal of Interactive Learning Online, 3(1), 1-11.

Hinson, J . M., \&LaPrairie, K. N. (2005). Learning to teach online: promoting success through professional development. Community College J ournal of Research and Practice, 29, 483-493.

Kane, R., Sandretto, S., \& Heath, C. (2002). Telling half the story: a critical review of research on the teaching beliefs and practices of university academics. Review of Educational Research, 72(2), 177-229.

Keengwe, J ., \& Kidd, Terry T. (2010). Towards best practices in online learning and teaching in higher education. J ournal of Online Learning and Teaching, 6(2).

King, K. P. (2002). Educational technology professional development as transformative learning opportunities. Computers \& Education, 39, 283-297.

Mahdizadeh, H., Biemans, H., \& Mulder, M. (2008). Determining factors of the use of elearning environments by university teachers. Computers \& Education, 51, 142154.

Meyer, K. A., \&Xu, Y.J . (2009). A causal model of factors influencing faculty use of technology. J ournal of Asynchronous Learning Networks, 13(2), 57-70.

Mitra, A., Lenzmeier, S., Steffensmeier, T., Avon, R., Qu, N., \&Hazen, M. (2000). Gender and computer use in an academic institution: Report from a longitudinal study. J ournal of Educational Computing Research, 23(1), 67-84.

MOE. (2008a). The number of e-learning courses in higher education. Retrieved from http:// epaper.edu.tw/topical.aspx?topical_sn=541

MOE. (2008b). The statistics of higher education. Retrieved from http:// www.edu.tw/ files/ site content/b0013/u.xls.

Morris, L., Xu, H., \& Finnegan, C. (2005). Roles of faculty in teaching asynchronous undergraduate courses. J ournal of Asynchronous Learning Networks, 9(1), 6582.

McQuiggan, C. A. (2007). The role of faculty development in online teaching's potential to question teaching beliefs and assumptions. Online J ournal of Distance 
Administration, 5(3). Retrieved from http:/ / www.westga.edu./ حdistance/ ojdia/ winter/ fall53/McQuiggan53.html

Munoz Carril, P. C., Gonzalez Sanmamed, M., \&Hernandez Selles, N. (2013). Pedagogical roles and competencies of university teachers practicing in the elearning environment. The International Review of Research in Open and Distance Learning, 14(3), 462-487.

Muir-Herzig, R. C. (2004). Technology and its impact in the classroom. Computers \& Education, 42(2), 111-131.

O'Neil, T. (2006). How distance education has changed teaching and the role of the instructor. Proceedings ISECON 2007, v24 (Pittsburgh). Retrieved from http:/ / proc.isecon.org/ 2007/2454/ISECON.2007.ONeil.pdf

Ryan, J., Scott, A., \&Walsh, M. (2010). Pedagogy in the multimodal classroom: An analysis of the challenges and opportunities for teachers. Teachers \& Teaching, 16(4), 477-489.

Ryan, S., Scott, B., Freeman, H., \& Paterl, D. (2000). The virtual university: The internet and resource-based learning. London: Kogan page Limited.

Saleh, H. (2008). Computer self-efficacy of university faculty in Lebanon. Educational Technology Research \& Development, 56(2), 229-240.

Salmon, G. (2000). E-moderating: The key to teaching and learning online. London: Kogan Page.

Schifter, C. (2002). Perception differences about participating in distance education. Online J ournal of Distance Learning Administration, 5(1). Retrieved from http:// www.westga.edu/ distance/ ojdla/ spring51/ schifter51.html

Sieverding, M., \&Koch, C. S. (2009). Self-evaluation of computer competence: how gender matters. Computers and Education, 31(2), 211-277.

Spector, J . M. \& de la Teja, I. (2001). Competencies for online teaching. ERIC Digest, 34.

Tao, Y. H. \&Yeh, C. C. (2008). Typology of teacher perception toward distance education issues - A study of college information department teachers in Taiwan. Computers and Education, 50(1), 23-36.

Vekiri, I. (2010). Boys' and girl's ICT beliefs: Do teachers matter? Computers and Education, 55, 16-23. 
Vodanovich, S., \& Piotrowski, C. (2005). Faculty Attitudes toward web-based instruction may not be enough: Limited use and obstacles to implementation. J ournal of Educational Technology Systems, 33(3), 309-318.

Wallhaus, R. A. (2000). E-learning: from institutions to providers, from students to learners. In R. N. Katz \&D. G. Oblinger (Eds.), The " $E$ " is for everything: ecommerce, e-business, and e-learning in higher education (pp. 21- 52). San Francisco, CA: J ossey-Bass.

West, R., Waddoups, G., \& Graham, C. (2007). Understanding the experiences of instructors as they adopt a course management system. Education Technology Research \& Development, 55(1), 1-26.

Zayim, N., Yildirim, S., \& Saka, O. (2006). Technology adoption of medical faculty in teaching: Differentiating factors in adopter categories. Educational Technology \& Society, 9(2), 213-222.

Zhou, G., \&Xu, J . (2007). Adoption of educational technology: How does gender matter? International J ournal of Teaching and Learning in Higher Education, 19, 140-153. 


\section{Appendix}

The Perceptions and Practices of E-instructors toward Online Instruction Questionnaire (PPEOIQ)

Dimension

(A) Instructional design (4 items)

(B) Facilitating learning (8 items)

(C)

Learning assessment (6 items)

(D)

Technology use (8 items)

(E)

Administration Management
Item questions

a1. I can design assignments that stimulate students' critical thinking skills.

a2. I can design assignments to enhance students' interactions.

a3. I can develop diverse group activities to enhance students' collaborative group works.

a4. I can develop learning objectives for lectures.

b1. I can design online social activities for participants to know each other quickly.

b2. By asking questions, I can encourage participants to share their thoughts.

b3. I can facilitate participants' discussion and help them focus on the related learning goals.

b4. I can summarize and provide participants' viewpoints from discussion forums to enhance their deeper learning and reflections.

b5. I can view and respond to questions (privately and publicly) submitted by participants.

b6. I can facilitate participants to form an online learning community.

b7. Using the LMS, I can monitor participants' collaborative group works.

b8. I can understand online participants' expectations and needs.

c1. I can set a clear policy on instructor responses and evaluation times.

c2. I can provide feedback to participants' individually about their learning progress.

c3. Within the course schedule, I can use the LMS tools to monitor participants' learning progress.

c4. In order to match the course instructional goals, I can plan appropriate evaluation formats.

c5. I can use devise strategies to evaluate participants' learning outcomes.

c6. I can set a clear criteria rubric on assignments to students.

d1. I can tell differences with traditional instructional media and online technology media.

d2. I can understand the limitations and functionalities of technology, platform, and information infrastructure.

d3. I am proficient in using e-learning multimedia and the LMS tools.

d4. According to instructional goals, I can chose technology appropriately for my online course.

d5. I can offer/ update consistency in delivery of information across courses.

d6. In order to ensure online participants' learning efficient, I can set a clear computer technology requirement guideline for them.

d7. In order to solve online participants' technical questions, I can provide the technical support guidelines for them.

d8. I can set a clear policy on respect copyright guidelines for online participants.

e1. I can stay tune in with distance education office staffs regarding online course enrollment issues (such as course credit, dropout ratio.). 
(6 items)

(F)

Content expertise (4 items)

(G)

Research development (4 items) e2. I can provide the course syllabus for online participants to keep their learning path.

e3. I can provide technical instructions clearly before participants have access to the LMS.

e4. I can meet with e-tutor(s) regularly in order to ensure the online instruction well-quality.

e5. In order to keep the LMS communication tools effectively, I can get good supports from e-learning technical staffs.

e6. I can set a clear policy on online etiquette and content with course discussion board and synchronous tools.

f1. I can prepare my instructional material (handouts, presentation, etc) in advance in order to delivery content to participants.

f2. I always update online learning resources to participants.

f3. I can enhance my professional knowledge and skills about elearning.

f4. In order to reinforce my professional development, I am willing to join scholarship communities.

g1. I can evaluate the validity and currency of online learning materials.

g2. After analyzing students' online learning activities, I can improve my instruction.

g3. I can collect research information about online instruction in order to update my instruction material.

g4. Based on instructional pedagogical theories, I can develop research issues related to the online instruction.

\section{Athabasca University $\mathbf{a}$}

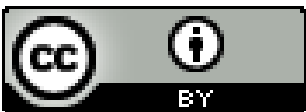

